\title{
Hybrid Journalism in an Online News Startup
}

\author{
Andika Wahyu Widyantoro ${ }^{1, *}$ Irwansyah $^{2}$
}

\author{
${ }^{1}$ Universitas Indonesia \\ ${ }^{2}$ Universitas Indonesia \\ *Corresponding author. Email: andikawahyu.dreamer@gmail.com
}

\begin{abstract}
The development of communication information technology contributes to the emergence citizen journalism (CJ) in the media. CJ is supported by new internet technologies, especially Web 2.0-based websites known as participatory webs. Through CJ and other types of user-generated content (UGC), members of the public express their opinions and raise issues of importance. Participatory users who use interactive modes are increasingly influencing the world of mainstream media, including online outlets. Media institutions adapt to the development of CJ, for example, by giving greater spaces for the public to publish works online. Furthermore, online media must adapt to CJ products, which are mostly distributed through social media. Online media are faced with two choices, namely, objectivity as a basic practice of journalism and engagement with users. Some media choose entrepreneurial journalism as an approach to building a news startup that embodies a certain form, namely, hybrid journalism. This form can be seen as the result of sliced CJ curves and professional media. This research article highlights how an online startup, Kumparan, practices both entrepreneurial and hybrid journalism. The study uses a qualitative method and case study strategy with online observation data collection and documentation about Kumparan. The results show that the practices of entrepreneurial and hybrid journalism are adaptations and survival steps to deal with changes in the media world, especially those related to traditional journalistic practices and engagement as a consequence of the strengthening of social media. The online media startup gives CJ greater access and space, including in editorials, which were previously closed to outsiders. This shows a future trend of journalism, namely, the growing development of cooperation, engagement, and collaboration between $\mathrm{CJ}$ and online media in the form of entrepreneurial and hybrid journalism.
\end{abstract}

Keywords: Citizen Journalism, Entrepreneurial Journalism, Hybrid Journalism, Internet, Online Media, Startup Media, User-Generated Content (UGC)

\section{INTRODUCTION}

In 2006, Time magazine declared "You" as the "Person of the Year," recognizing how individuals play a role in societies where online communication is prominent (Grossman, 2006). The choice of "You" acknowledged the growing influence that users and usergenerated content (UGC) or user-created content (UCC) have in media, including citizen journalism (CJ).

Time's front cover announcing the Person of the Year was a way that the editors thanked millions of anonymous and non-anonymous web users who contributed their creativity to support the rapid increase of web-based culture through various UGC (Van Dijck, 2009).

The development of internet-based information and communication technology is encouraging the emergence of space for online communities and the existence of shared information resources that enable a coordinated mode of new efforts and open online communities to bring forth UGC (Crowston and Fagnot, 2018). In CJ, the audience no longer only receives news but is also involved in news production and distribution (Bowman and Willis, 2003). The role of information and communication technology is a vital factor that has enabled the birth and development of CJ.

UGC, including CJ, comes from ordinary people who voluntarily donate data, information, or media that can then be displayed online to others (Krumm, Davies, and Narayanaswami, 2007). The growing popularity of CJ today is triggered by the presence of new technology media that have led to increased accessibility to information for the general public (Hughes, 2010). 
Information and communication technology devices such as smartphones, which are equipped with the ability to record videos, photos, and operating system-based applications, make it easy for ordinary citizens to produce and disseminate the information they generate.

CJ can be interpreted as activity by citizens or groups of citizens in the process of gathering, reporting, analyzing, and disseminating news that aims to provide information that is independent, reliable, accurate, broad, and relevant to the course of democracy (Bowman and Willis, 2003).

The development of CJ as one form of UGC cannot be separated from the growing development of information technology and the wider use of technology such as smartphones.

The results of Global Digital 2019 research conducted by Hootsuite and We Are Social show that internet users globally grow by an average of more than one million new users every day. There are 5.11 billion cellphone users in the world today or up to 100 million users compared to 2018. Internet users now number 4.39 billion, an increase of 366 million from January 2018. In 2019 , there are 3.48 billion social media users. As of January 2019, 3.26 billion people used social media on their mobile devices (Kemp, 2019).

Meanwhile, in the Indonesian context, the number of mobile subscriptions was 355.5 million or 133 percent compared to the total population of 268.2 million. Internet users in Indonesia have reached 150 million people, with active social media users as many as 150 million and social media mobile users totaling 130 million. The most popular social media platforms are YouTube, WhatsApp, Facebook, Instagram, Line, Twitter, FB Messenger, BBM, LinkedIn, and Pinterest (Kemp, 2019).

The rapid development in platforms that facilitate participatory internet activities has expanded user opportunities for the production and consumption of online content (Kaplan and Haenlein, 2010).

CJ holds an increasingly important position in today's news media environment. The mainstream media's response to CJ is very diverse and multifaceted, ranging from rejection to acceptance with reluctance, competition, and guarding to the limits of its differences (Wall, 2017).

Entrepreneurial journalists are pioneering hybrid journalism (Wagemans, Witschge, and Harbers, 2019), and online media startups are one form of entrepreneurial journalism. Startup media and startup companies have different characteristics from conventional media institutions, for example, in terms of the speed of adaptation and continuous search for ways to advance journalistic practices (Naldi and Picard, 2012; Wagemans, Witschge, and Deuze, 2016).
Media must adapt to the growing CJ, which is mostly produced, distributed, and consumed through social media. One step in this adaptation is hybrid journalism, which can develop faster in media that grows entrepreneurial journalism, carried out through online media startups.

Hybrid journalism developed as a response to changing trends in the world of media, especially the strengthening of social media. On the one hand, media institutions are expected to be objective as part of good journalistic practices, but on the other hand they are also now faced with demands for engagement with the audience through social media (Ruotsalainen and Villi, 2018). Hybrid journalism in this context is used as a bridge connecting the world of professional media and users who are increasingly accustomed to personalized interfaces.

Scholars see hybrid journalism as one of the journalistic practices that will continue to develop in the future (Newstex, 2018; Ruotsalainen, Hujanen, and Villi, 2019). The future of journalism is a hybrid and adapts to all support. This supports changes in the information model that the media cannot avoid, especially aspects of media relations with the audience (Edo, 2010).

Kumparan declared itself as a startup media in Indonesia. It was first launched in January 2017, with the purpose of being the first platform in Indonesia to incorporate technology-based journalism and enable interaction between all users into one platform. Kumparan takes a progressive step in carrying out its journalistic practices by using hybrid journalism, for example, by opening the door wide for $\mathrm{CJ}$ to create and facilitate content through the various features available.

This research focuses on two aspects: 1) what is the form and implementation of hybrid journalism on Kumparan? 2) Why does Kumparan appear as a startup media?

Relatively few studies have addressed entrepreneurial journalism, especially the conceptions about journalism and the actual journalism they produce (Singer, 2017 in Ruotsalainen and Villi, 2018). Ruotsalainen and Villi (2018) enriched the discussion of this theme on what constitutes the ideas, approaches, and values of entrepreneurial journalism.

Entrepreneurial journalism is studied in relation to hybrid journalism, to clarify what hybrid news journalism could be like in practice and how it may evolve in the future (Ruotsalainen and Villi, 2018).

Meanwhile, in Indonesia, research on hybrid journalism has also been relatively sparse. One of the few studies on hybrid journalism was done by Lase (2015). The study criticized that the practice of hybrid journalism carried out on Kompasiana.com is a form of McDonaldization because its principles of efficiency, 
calculation, predictability, and technological control lead to content homogenization, decreased journalistic quality, and misuse of the concept of CJ.

This research differs from previous works because it describes the novelty of a hybrid journalism practice in Indonesia, which is not only seen in terms of the final result (i.e., news) but also in terms of a systemic, discursive, and textual perspective. This study also discusses the efforts of online startup media in mediating the basic demands of journalism, such as objectivity and engagement with users in the realm of social media. This research can encourage further discussion about future journalistic trends, specifically the theme of entrepreneurial and hybrid journalism in the Indonesian context.

\section{LITERATURE REVIEW}

\subsection{Citizen Journalism}

CJ is a form of UCC or UGC (OECD, 2007). The term has no standard definition, and the concept is known not only as CJ (Hermida and Thurman, 2008; Konieczna, Hatcher, and Moore, 2018; Noor, 2008) but also as participatory journalism (Domingo et al., 2008; Fröhlich, Quiring, and Engesser, 2012) or democratic journalism (Baase, 2008).

CJ refers to journalistic activities carried out by ordinary people, where citizens report the problems they face. It allows citizens to express themselves and raise issues that are important to the public and outsiders (Noor, 2008).

In addition, CJ has various synonyms: stand-alone journalism, public journalism, open source journalism, networked journalism, crowd-sourced journalism, collaborative journalism, community journalism, grassroots journalism, and bridge media (Cohn, 2007). The common thread among these various terms is that they refer to the activities of ordinary citizens who engage in journalism. Ordinary citizens are distinguished from professional mainstream media journalists.

The terms "citizen journalism" and "participatory journalism" are often used interchangeably in reference to the actions of citizens, or groups of citizens, who play an active role in the process of collecting, reporting, analyzing, and disseminating news and information (Bowman and Willis, 2003). In this article the author uses the term "CJ" with consideration of consistency in the explanation and discussion related to the theme of the research.

The term "citizen journalism" did not exist before the advent of the internet because $\mathrm{CJ}$ grew along with the presence of interactive functions on the internet. The various forms of $\mathrm{CJ}$, such as blogs, forums, and photos or videos uploaded to the media, all contribute to journalistic content that supports the process of forming news (Room, 2013).

In its early stage, CJ developed along with Web 2.0 technology, known as the participatory web, which created the opportunity for audiences that were previously passive in receiving information from mainstream media to become empowered by producing their own UGC (Kang, 2016).

This brought on a new hybrid of production and simultaneous use called "produsage" (production and usage) (Bruns, 2007). Produsage describes the practice of creating and developing collaborative content in contemporary information environments.

In the produsage model, ideas are produced in an environment that is collaborative and participatory in nature so that it blurs boundaries between producers and consumers and conversely allows all participants to become users and producers of information and knowledge (Bruns, 2007). User participation is framed through consumer choices, namely, through registration and user-agreed agreements, disclaimers, and features that can be easily chosen (Chia, 2011).

Chia (2011) further argues that UGC differs from its empowerment rhetoric because as a sociotechnical configuration, UGC promotes choice, participation, and agency but provides a mode of "governmentality" that encourages users to enter a predetermined, narrowly defined productivity mode by the system. Meanwhile, as a platform ecosystem, UGC can offer democracy, individualization, fame, and wealth.

Associated with UGC, including CJ, "governmentality" or the first rule of conduct that must be done is through activities called registration (Bordewijk and van Kaam, 1986). This registration refers to everything that regulates and determines limits on user activity on a platform.

Through registration rules, organizations receive information from users that is documented and stored on the system which also functions as a monitoring feature. One potential for communication registration, which is computer and internet mediated, is the organization's actions of using cookies to track and customize content for visitors to the website (McMillan, 2002).

Meanwhile McMillan (2002) argues that four communication models can be used to explain interactivity in cyberspace, including in this case UGC and CJ. The two main dimensions, namely, the direction of communication and the level of recipient control over the communication process, are the main framework for interactivity in the cyber world mediated by computers. The next model is perception-based and feature-based. The perception-based model refers to things perceived by the subject or user, while the feature-based model is more related to tools for site development that include 
more features to increase the level of interactivity (McMillan, 2002).

Internet-based interactivity refers to the desire of site developers who provide wider opportunities for users to interact, move, and network, especially by producing content, spreading it at the same time as consuming it. This is referred to as "mutual discourse" by McMillan (2002) which describes an unfettered environment that allows free two-way communication that all visitors have the potential to participate in the site as senders and recipients. Everyone has the opportunity to contribute in their own ways.

The recent trend, UGC, including CJ, is considered to have a very high level of quality and variation that is comparable to works produced by professionals (Xiaohua and Liyuan, 2013).

\subsection{Online News Startups as Entrepreneurial Journalism}

Entrepreneurial journalism is as likely to be described in terms of an "entrepreneurial spirit" as it is a specific practice or set of practices. It represents a fervent hope for the future in the midst of an uncertain present. Entrepreneurialism in the media world is not only acceptable but even vital for survival in the digital age (Vos and Singer, 2016).

Entrepreneurial journalism can be described as journalism that 1) is produced by new media outlets established by journalists themselves, 2) reflects the personalities, goals, and visions of the founders, 3) seeks to renew journalism by addressing new niches, exploring new styles and formats, and building a new relationship with the audiences, and 4) pursues a sustainable business based on these attributes (Ruotsalainen and Villi, 2018).

The top eight keywords in the literature about startups, in order of importance, are innovation, network, technology, entrepreneurship, open innovation (OI), venture capital (VC), startups, and transfer (Spender et al., 2017). Innovation is the most frequently used term in the startup world.

Entrepreneurial journalists pioneer hybrid journalism (Wagemans, Witschge, and Harbers, 2019). Hybrid journalism merges the dialogical and objective traditions of journalism. Objectivity and dialog are competing ideals in the practice of journalism (Soffer, 2009).

For-profit digital news startups backed by large investors, VC, and technology entrepreneurs have taken on an increasingly significant role in the journalism industry (Carlson and Usher, 2016).

Entrepreneurial journalism startups and other enterprises are labeled as experimental, independent, young, and nimble. They do not represent the collapse of the journalistic field but rather a reconstitution of a norm of the field (cultural and capital) (Vos and Singer, 2016).

Startup companies, including online media startups, are powerful engines of OI processes. Startup companies are intrinsically open organizations, necessarily engaged in innovation processes (Spender et al., 2017).

There are four discourses of entrepreneurial journalism: the 1) identity discourse (media outlets as persons), 2) niche discourse (going deeper), 3) network discourse (rhizomatic media), and 4) change discourse (the reformists) (Ruotsalainen and Villi, 2018).

In the identity discourse, the media signify themselves as human-like individuals with their own identity and personality. In the niche discourse, the media emphasize how they concentrate and specialize, where niche refers to the specific journalistic approaches and voices rather than narrow topics. The network discourse signifies media as nodes in networks. In the change discourse, the media present themselves as change actors: as reformers of media, journalism, and society (Ruotsalainen and Villi, 2018).

From these discourses, Ruotsalainen and Villi (2018) later sketch four scenarios for the future of entrepreneurial journalism: 1) elitist-individualists identity, 2) communalists, 3) public service, and 4) identity media.

In elitist-individual identity, entrepreneurial journalists offer their journalism to educated "elite" audiences. Communalist entrepreneurial journalism outlets are built around the audience, which is closely involved. In public service, entrepreneurial journalists offer their products to the general public. In identity media, entrepreneurial journalism outlets focus on helping audiences construct their identities (Ruotsalainen and Villi, 2018).

\subsection{Hybrid Journalism}

Hybrid journalism comes to answer a key question for the future of journalism, that is, how journalism can reestablish a connection with its audience while also preserving its own autonomy. Hybrid journalism arguably entices rich hybrid engagement, which appeals to both rational and affective sentiments in the audience (Ruotsalainen and Villi, 2018).

Hybridity has become a decisive feature that manifests at various levels: 1) systemic, 2) discursive, and 3) textual. Systemic hybridity refers to the melding of technological affordances, economic agendas, and structures of media production and distribution. Discursive hybridity refers to the blending of journalistic discourses or "linguistic consciousness." Textual hybridity describes the blending of genres, forms, and styles. These three levels of hybridization challenge the traditional conception of journalism and at the same time 
enable the emergence of new forms of journalistic truth reporting (Baym, 2016).

Hybrid journalism offers a solution to the potentially contradicting ideals of engagement and objectivity that arguably suit social media platforms with their conversational and affective registers better than the traditional media's detached type of journalism and potentially makes journalism more attractive for audience participation (Ruotsalainen and Villi, 2018).

The future of journalism is hybrid and adapts to all supports, like the work of journalists, publishers, narration, formats, sections, investments, publicity and, above all, the relationship of the media with the audience (Edo, 2010).

\section{METHOD}

This study uses qualitative methods and case study strategies with the data collection methods of observation and documentation study.

The researcher observed how an online media startup in Indonesia, Kumparan, practices entrepreneurial and hybrid journalism. This practice was observed by web and virtual observation of the vision and mission stated in the "About us" section, various journalistic practices seen on websites and applications, the relation and collaboration with the audience, and documentation.

The findings and discussion in this single case study are then explained narratively to provide a thorough understanding of the practice of hybrid journalism in the online media startup Kumparan.

\section{FINDINGS}

\subsection{Kumparan as an Online Media Startup}

After beginning development in mid-2016, Kumparan launched a beta version in the form of websites, as well as Android and iOS applications, in January 2017 (Pratama, 2018). Kumparan states its purpose is to be the first platform in Indonesia to incorporate technology-based journalism and enable interaction between all users on one platform.

Unlike mainstream media in Indonesia, Kumparan proclaims as an online media startup. Kumparan can be accessed on mobile devices, personal computers, and other surfaces. The company uses the Personalization Algorithm Technology that to distribute its products or good quality contents to the right people and at the right time.

Then, Kumparan as hybrid media startup announced an unspecified amount of funds from Global Digital International (GDI), the GDP Venture investment unit on July 2017. The funds raised will be used for recruitment and strengthening the technology team and business development team. GDI representatives said they were interested in the concept of hybrid news providers as Kumparan employs a new approach in the Indonesian media industry, where readers can also participate and interact with others about various news topics. (Karimuddin, 2017).

One year later, one of the decacorns in Indonesia, Go-Jek, also announced its investment in Kumparan, although it did not specify the nominal value (Setyowati, 2018).

Kumparan tries to present a hybrid platform that unites editorial-based and community-generated content. With its vision of redefining the country's media industry through "people power," Kumparan tries to find new approaches and new patterns in modern journalism where the concept of social media is broadly adopted in the user experience. Co-Founder and Kumparan Marketing Director Andrias Ekoyuono said that the platform the company wants to achieve is not just a new one but one that is adjusted to various media elements with a more appropriate approach (Eka, 2017).

Then, in 2018, Kumparan became the only Indonesian startup invited by Facebook to take part in the FbStart program at Facebook's headquarters, Menlo Park, California, United States. The program provides various trainings, technical assistance, and tools that can be used by startups to accelerate their growth (kumparantech, 2018).

Kumparan said the principle that distinguishes the company from other media is that it does not consider technology as a supporting pillar but rather as the main foundation, and then this is what drove the decision to build a platform that combines the concept of news sites with social media (Pratama, 2017).

As a startup, one of the distinctive forms of the Kumparan is that in the editorial board there are three divisions: collaboration, programs, and social media.

One other thing about Kumparan that is typical of startups is the implementation of the Employee Stock Option Plan system so that employees have the right to gain ownership of shares (Pratama, 2017). This practice does not occur in traditional media.

\subsection{Hybrid Journalism Practice in Online Media}

Kumparan, through the collaboration division, programs, and social media, looks for various ways and open access for the audience to collaborate. This is listed in the community guide that explains how users can join and do collaborative work with Kumparan.

The first thing that must be done by the user to be able to send their news, photos, or videos to Kumparan is fill out the registration form and agree to the terms and 
conditions. After completing this initial process, users can begin their CJ activities. They must fill out a Google doc form to verify their identity. The form asks for information such as full name, e-mail, identity card number, Facebook account, Twitter account, Instagram account, and mobile number. Users are also required to upload photos of their national ID cards.

Furthermore, the user must choose one of the two user preferences offered: (1) users who only read, like, comment, and share news, or (2) users who write. Users cannot create and broadcast their work directly but must go through a process of moderation. This activity can be interpreted as a step of review so that UGC does not violate the agreed rules and conditions.

Kumparan states that they consider and assess conditions that require censor action both for stories, comments, and UGC. Kumparan determines whether content for users matches or violates the community guidelines, terms of service, privacy policies that have been created. Kumparan provides freedom that is responsible to users who upload comments, with the consequences of the risk being the responsibility of the user.

If the content is judged to be good and prospective, Kumparan can promote the content to the timeline or editor-selected content. To maintain the quality of content, Kumparan has the right to make edits, such as spelling repairs, visual stories, or the addition of illustrations that support it without changing the contents of the story. While the story is not promoted, there is no need to go through the editing process by the editorial staff.

Kumparan can promote user-created stories to materials and sources that are further processed into stories written by the company's editorial team. Furthermore, Kumparan can promote a story by including the name or hyperlink of the user account. The company opens the door open wide for collaboration with CJ. Users can write about and send photos related to any theme on the website. UGC can be published parallel or side by side with the work of professional Kumparan journalists.

Kumparan can use user-made CJ products as additional material for its news production, in which the editorial team can use $\mathrm{CJ}$ stories as news development material.

Kumparan develops CJ products if they are judged to have several criteria such as: 1) have a strong story telling; 2) contain new information or exclusive information; 3) contain a good aesthetic element and potentially go viral; 4) contain elements of strong emotion that are evocative, intriguing, or satirical; invite people to think and interact; are humorous; or inspire enthusiasm.
After opening the editor's door to users so they can collaborate on and publish CJ content, Kumparan went further by creating a program called 1001 Startup Media Online that has attracted more than a thousand registrants. The program teaches young people aged $21-$ 30 years to create their own online startup media. Kumparan will share editorial knowledge as well as business, and selected startups will receive operational costs of IDR 3.5 billion (USD 2.500.000). Twenty-five selected participants will collaborate to create online media by utilizing Kumparan's platform to produce quality content from all over the country.

In addition to providing opportunities and more space for users to publish content, Kumparan embeds features that can help users interact with the online materials, such as the author's follow feature and hashtag for various topics. Through these features, users and journalists can follow each other so that they can receive writing updates and more personalized content. Vice versa, Kumparan can deliver various types of news personalized to the users.

Kumparan states the principle that distinguishes the startup from other media is that it does not consider technology as a supporting pillar but rather as the main foundation. Then, it decided to build a platform that combines the concept of news sites with social media (Pratama, 2017).

\subsection{Method}

$\mathrm{CJ}$ is an important part of the media industry, and it grows as social media develops. The media is aware of this change and is adapting to it, for example, by implementing entrepreneurial and hybrid journalism. Both of these are steps for the survival of the media.

Audiences, in this case, users, will be an important part of journalism in the future (Rosenstiel, 2013). Mainstream media, including online media, acknowledge that the role of users, especially in CJ, is important for their existence and development. Online media can use incentives to attract the attention of users and encourage them to participate in creating content. Therefore, the media then provide space and access for CJ activities. This reality can be seen as the fading line that separates professional journalists and their audiences (Jenkins, 2006).

The relationship between $\mathrm{CJ}$ and professional media is deeper in the practice of entrepreneurship and hybrid journalism. The media is aware that traditional media institutions that only rely on pure journalistic products and do not pay attention to engagement and social media will be threatened.

News startups must be recognized as a view into the future - both as journalism and business organizations. The news may be delivered through a website, a mobile 
app, or a social networking platform like Facebook or Twitter. Innovation and experimentation are key (Marsden, 2017).

The media, especially online media startups, take drastic steps, for example by choosing the form of company as a startup, not like traditional media. This is because the form of startups is considered more likely to move quickly and be adaptive to changes.

The consequence of entrepreneurial journalism in the form of startups is that the media are always looking for new forms and gaps for innovation, especially related to the increasing power of social media.

Hybrid journalism can invoke hybrid engagement, which appeals to both rational and affective sentiments in the audience (Ruotsalainen and Villi, 2018). The use of follow and hashtag (\#) features in Kumparan is a technical step for engagement with the audience.

Collaboration is one of the main practices in the online media startup ecosystem. Kumparan, in addition to providing a space for collaboration for the audience, also encourages them to create their own online media startup. Kumparan then provides assistance programs for both journalism and business. This shows that while pursuing engagement with an audience on social media, it still focuses on the quality of journalistic products.

The first step that users must take in order to have access to mainstream media is to register. User participation is formed through consumer choice, namely, through registration and user-agreed agreements, disclaimers, and features that can easily be chosen (Chia, 2011). Registration refers to a number of things that regulate and determine the limits of user activity on a platform (Bordewijk and van Kaam, 1986).

This registration is important for the media because it functions as a filter for users who will carry out CJ activities. The media even takes a step further than registration, namely, the obligation to upload a national identity card. Data verification is vital for the media because it can reduce anonymous accounts and make users more responsible for the content they generate.

Suau and Masip (2013) distinguished three types of interactions that may occur in the interactivity process: selective interactivity, participatory interactivity, and productive interactivity. As they defined, selective interactivity is a set of features and services that allow users to interact with the system to adjust content according to their preferences, including personalization mechanisms. An example of selective interactivity is registration. Meanwhile, participatory interactivity allows users to interact with journalists and other users. The forms of this interaction are, for example, comments or ratings and sharing features. Productive interaction is a condition where users contribute through content for themselves, such as in the form of writing news or sending photos and videos.

Online media moderates or censors UGC so users cannot automatically publish content. This moderation can be seen as a media effort to maintain the quality of the journalistic products. Media standard broadcasting procedures are carried out, including for $\mathrm{CJ}$ production content.

Moderation features are used for UGC in CJ due to the concerns of the media editorial team regarding reputation, trust, and legal obligations. The media treats CJ products by adopting traditional "gatekeeping" approaches commonly used by media institutions. This gatekeeping approach can be a model for CJ product integration with professional media organizations (Zeller and Hermida, 2015).

Kumparan sometimes allows CJ to broadcast content without going through moderation. The moderation process is only done on $\mathrm{CJ}$ content promoted by Kumparan because it is considered potential viral news or because the quality of writing/photos/videos is rated above average.

Kumparan can use UGC on CJ as an ingredient for developing journalistic work. This shows the practice of collaboration between media as a professional institution with CJ users.

CJ will not replace or shift the practice of mainstream journalism but only be complementary (Neuberger and Nuernbergk, 2010). Journalism in the future is expected to become an arena of $\mathrm{CJ}$ cooperation and mainstream media in delivering news (Hughes, 2010).

\section{CONCLUSION}

The development of information and communication technology has played an important role in the birth and development of CJ. Through the mediation of new technology, audiences or users can be involved in the production and dissemination of news content, not just passively receiving news as in the previous era.

Media is now faced with the next challenge, that is, the strengthening of social media. If traditional media only rely on their journalistic side without paying attention to engagement with the audience and social media, then their existence as media will be threatened.

This has led to the further development entrepreneurial journalism, for example, in the form of online media startups with prominent characteristics such as innovation and networking, technology, and entrepreneurship.

Hybrid journalism can be seen as an innovation that bridges the needs of the media and users. Hybrid journalism can invoke hybrid engagement, which 
appeals to both rational and affective sentiments in the audience (Ruotsalainen and Villi, 2018).

Entrepreneurial and hybrid journalism will greatly influence journalism in the future. This finding can be the basis for future research related to journalistic practices, especially those of startup online media and hybrid journalism.

\section{REFERENCES}

[1] Baase, S. (2008). A gift of fire (3rd ed). Lebanon: Prentice Hall.

[2] Baym, G. (2017). Journalism and the hybrid condition: Long-form television drama at the intersections of news and narrative. Journalism: Theory, Practice and Criticism, 18(1), 11-26. DOI: https://doi.org/10.1177/1464884916657521

[3] Bordewijk, J. L., \& van Kaam, B. (1986). Towards a new classification of tele-information services (pp. 16-21). London: Intermedia, 34(1).

[4] Bowman, B. S., \& Willis, C. (2003). We media. Retrieved from http://www.mediacenter.org/mediacenter/research/ wemedia/. VA: Reston

[5] Bruns, A. (2007). Produsage: Towards a broader framework for user-led content creation. Retrieved from http://eprints.qut.edu.au. InProceedings creativity and cognition 6 . DC: Washington

[6] Carlson, M., \& Usher, N. (2016). News Startups as Agents of Innovation: For-profit digital news startup manifestos as metajournalistic discourse. Digital Journalism, 4(5), 563-581. https://doi.org/10.1080/21670811.2015.1076344

[7] Chia, A. (2012). Welcome to Me-mart. American Behavioral Scientist, 56(4), 421-438. https://doi.org/10.1177/0002764211429359

[8] Cohn, D. (2007). Time citizen journalism pulled its acts together. Retrieved from https://www.pressgazette.co.uk/time-citizenjournalism-pulled-its-acts-together/

[9] Crowston, K., \& Fagnot, I. (2018). Stages of motivation for contributing user-generated content: A theory and empirical test. International Journal of Human-Computer Studies, 109(June), 89-101. https://doi.org/10.1016/j.ijhcs.2017.08.005

[10] Domingo, D., Quandt, T., Heinonen, A., Paulussen, S., Singer, J. B., \& Vujnovic, M. (2008). Participatory journalism practices in the media and beyond: An international comparative study of initiatives in online newspapers. Journalism
Practice, 2(3), 326-342. https://doi.org/10.1080/17512780802281065

[11] Edo, C. (2010). Journalism's future is hybrid and adapts to all supports. Iberoamerican Communication Review, 2, 119-128.

[12] Eka, R. (2017). Debut Versi Beta kumparan dengan Strategi "People Power." Retrieved from https://dailysocial.id/post/kumparan-strategipeople-power

[13] Fröhlich, R., Quiring, O., \& Engesser, S. (2012). Between idiosyncratic self-interests and professional standards: A contribution to the understanding of participatory journalism in $\mathrm{Web}$ 2.0. Results from an online survey in Germany. Journalism: Theory, Practice and Criticism, 13(8), 1041-1063.

https://doi.org/10.1177/1464884912442282

[14] Grossman, L. (2006). Time's person of the year. you. Retrieved from http://content.time.com/time/magazine/article/0,917 1,1570810,00.html

[15] Hermida, A., \& Thurman, N. (2008). A clash of cultures: The integration of user-generated content within professional journalistic frameworks at British newspaper websites. Journalism Practice, 2(3),

343-356. https://doi.org/10.1080/17512780802054538

[16] Hughes, W. (2010). Citizen journalism: Historical roots and contemporary challenges.

[17] Kang, I. (2016). Web 2.0, UGC, and citizen journalism: Revisiting South Korea's OhmyNews model in the age of social media. Telematics and Informatics, 33(2), 546-556. https://doi.org/10.1016/j.tele.2015.07.007

[18] Kaplan, A. M., \& Haenlein, M. (2010). Users of the world, unite! The challenges and opportunities of Social Media. Business Horizons, 53(1), 59-68. https://doi.org/10.1016/j.bushor.2009.09.003

[19] Karimuddin, A. (2017). kumparan Peroleh Pendanaan dari Grup GDP Venture. Retrieved from https://dailysocial.id/post/kumparan-perolehpendanaan-dari-grup-gdp-venture

[20] Kemp, S. (2019). Digital 2019: Global internet use accelerates. Retrieved from https://wearesocial.com/blog/2019/01/digital-2019global-internet-use-accelerates

[21] Konieczna, M., Hatcher, J. A., \& Moore, J. E. (2018). Citizen-centered journalism and Contested Boundaries: Innovations and limitations at three news organizations. Journalism Practice, 12(1), 418.

https://doi.org/10.1080/17512786.2016.1269292 
[22] KrumSchnoor, J. L., Davies, N., \& Narayanaswami, C. (2007). ES\&T: User-generated content. Environmental Science and Technology, 41(13), 4487-4487. https://doi.org/10.1021/es0725605

[23] kumparantech (2018). kumparan Satu-satunya Startup Indonesia di Program FbStart 2018. Retrieved from https://kumparan.com/@kumparantech/kumparansatu-satunya-startup-indonesia-di-program-fbstart

[24] Marsden, P. (2017). Entrepreneurial journalism. Entrepreneurial Journalism. https://doi.org/10.4324/9781315641096

[25] Mcmillan, S. J. (2002). A four-part model of cyberinteractivity: Some cyber-places are more interactive than others. New Media and Society, $4(2)$, 271-291. https://doi.org/10.1177/146144480200400208

[26] Naldi, L., \& Picard, R. G. (2012). 'Let's start an online news site': Opportunities, resources, strategy, and formational myopia in startups. Journal of Media Business Studies, 9(4), 69-97. https://doi.org/10.1080/16522354.2012.11073556

[27] Neuberger, C., \& Nuernbergk, C. (2010). Competition, complementarity or integration?: The relationship between professional and participatory media. Journalism Practice, 4(3), 319-332. https://doi.org/10.1080/17512781003642923

[28] Newstex (2018). Nieman Journalism Lab: Hybrid, a collection of targeted news sites in Asia, embraces growing slowly and knowing its audience.: Chatham Publishing.

[29] Noor, B. R. (2008). Citizen Journalism vs. Mainstream Journalism: A Study on Challenges Posed by Amateurs, 3(1), 55-76.

[30] Pratama, A. H. (2017). Pendiri dan Mantan Karyawan Detik Bangun Kumparan.

[31] Pratama, A. H. (2018). [Update]. GO-JEK Resmi Memberikan Investasi kepada Startup Media Online kumparan. Retrieved from https://id.techinasia.com/rumor-pendanaankumparan-go-jek

[32] Room, O. N. (2013). Citizen Journalism: A primer on the definition, risks and benefits and main debates in media communications research. opennewsroom.com. Retrieved from http://www.theopennewsroom.com/documents/Citi zen_journalism_phenomenon.pdf (pp. 1-9)

[32] Ruotsalainen, J., Hujanen, J., \& Villi, M. (2019). A future of journalism beyond the objectivitydialogue divide? Hybridity in the news of entrepreneurial journalists. Journalism. https://doi.org/10.1177/1464884919867216

[33] Ruotsalainen, J., \& Villi, M. (2018). Hybrid engagement: Discourses and scenarios of entrepreneurial journalism. Media and Communication,

6(4)NewsandParticipationthroughandbeyondPropri etary), 79-90. DOI: https://doi.org/10.17645/mac.v6i4.1465

[34] Setyowati, D. (2018). Go-Jek Dikabarkan Tanam Modal di Kumparan. Retrieved from https://katadata.co.id/berita/2018/09/07/go-jekdikabarkan-tanam-modal-di-kumparan $\% 0 \mathrm{~A}$

[35] Soffer, O. (2009). The competing ideals of objectivity and dialogue in American journalism. Journalism: Theory, Practice and Criticism, 10(4), 473-491.

https://doi.org/10.1177/1464884909104950

[36] Spender, J. C., Corvello, V., Grimaldi, M., \& Rippa, P. (2017). Startups and open innovation: A review of the literature. European Journal of Innovation Management, 20(1), 4-30. https://doi.org/10.1108/EJIM-12-2015-0131

[37] Van Dijck, J. (2009). Users like you? Theorizing agency in user-generated content. Media, Culture and Society, 31(1), 41-58. https://doi.org/10.1177/0163443708098245

[38] Vos, T. P., \& Singer, J. B. (2016). Media discourse about entrepreneurial journalism. Journalism Practice, 10(2), 143-159. https://doi.org/10.1080/17512786.2015.1124730

[39] Wagemans, A., Witschge, T., \& Deuze, M. (2016). Ideology as resource in entrepreneurial journalism: The French online news startup mediapart. Journalism Practice, 10(2), 160-177. https://doi.org/10.1080/17512786.2015.1124732

[40] Wagemans, A., Witschge, T., \& Harbers, F. (2019). Impact as driving force of journalistic and social change. Journalism, 20(4), 552-567. https://doi.org/10.1177/1464884918770538

[41] Wall, M. (2017). Mapping Citizen and Participatory Journalism: In newsrooms, classrooms and beyond. Journalism Practice, 11(2-3), 134-141. https://doi.org/10.1080/17512786.2016.1245890

[42] Zeller, F., \& Hermida, A. (2015). When tradition meets immediacy and interaction. About journalism, 4, No. 1, 106-119.

[43] Zeng, X., \& Wei, L. (2013). Social ties and user content generation: Evidence from Flickr. Information Systems Research, 24(1), 71-87. https://doi.org/10.1287/isre.1120.0464 